\title{
HUMAN RIGHTS IN THE ACTIVITIES OF LAW ENFORCEMENT OFFICIALS
}

\section{Roman I. Blahuta1, Olha O. Barabash², Vasyl P. Zakharov³, Mariia Yu. Kovalska4, Kateryna R. Dobkina ${ }^{5}$}

Lviv State University of Internal Affairs, Lviv, Ukraine1; Department of General Law Disciplines, Institute of Law, Lviv State University of Internal Affairs, Lviv, Ukraine2; Department of Operative Investigative Activity, Institute for the Training of Specialists for National Police, Lviv State University of Internal Affairs, Lviv, Ukraine3; Department of Criminal Procedure and Forensic, Institute for the Training of Specialists for National Police, Lviv State University of Internal Affairs, Lviv, Ukraine; ; Faculty of Law, Institute of Management, Technology and Law, State University of Infrastructure and Technologies, Kyiv, Ukraine ${ }^{5}$

\section{Abstract}

The importance of respect for human rights in a democratic society and, especially, by the state makes this research topic relevant. However, the current situation in Ukraine is evidence that such rights are often broken, and although law enforcement officials should protect these rights, they are those who break them. The study aims to explore the role of law enforcement activities in ensuring and protecting human rights in Ukraine, examine existing problems at the legislative and practical level, and find ways to improve the current situation. The article studies the case law of the European Court of Human Rights. On its basis, it substantiates there are significant problems in the Ukrainian reality regarding the respect for human rights by law enforcement officials. Based on this, we have suggested effective methods to eliminate these breaches, such as establishing additional control over the activities of law enforcement officials and reforming their education system. As the changes and reforms should start with a terminological definition, we have emphasized the need to amend the current legislation of Ukraine that will eliminate contradictions and inaccuracies in the interpretation of the notion of law enforcement officials. The practical significance of the article is to prepare the basis for amendments to the legislation of Ukraine and the training system of law enforcement officials. In addition, the practical significance of the work is to justify the need for an online platform for society to control the activities of law enforcement officials in terms of their respect for human rights and freedoms.

Keywords: human rights, law enforcement officials, the European Court of Human Rights, protection of human rights, public authorities.

\section{INTRODUCTION}

The activities of law enforcement officials are crucial for any democratic society as the state can be characterized as democratic only if it recognizes and guarantees human rights, and consequently, is obliged to protect them. When the state supports the participation of citizens in public and state life, it shows the level of its democratic development, prevents from breaking human rights, and turns the activities of public 
authorities for ensuring and protecting such human rights and freedoms $/ \mathbf{1} /$. The importance of law enforcement officials consists in their activities as the level of ensuring the rights and freedoms of citizens is an indicator of state development.

The role of law enforcement officials in the exercise of guaranteed human rights and freedoms is difficult to overestimate as they are intended to support the rights and freedoms enshrined in the Constitution of Ukraine and the legislation to be exercised to the full extent. According to the Constitution of Ukraine, the desire to develop and strengthen a democratic state is impossible to realize without the consolidation of inalienable human rights and freedoms in the public consciousness and social practice and other guarantees at the regulatory level $/ \mathbf{2} /$. The state must be active in ensuring human rights and creating material, organizational, social, political, and other conditions for the person to exercise his or her rights and freedoms to the full extent.

The issues of ensuring rights and freedoms are dealt with by all, without exception, fields of law, but their role is not the same in this process. In this regard, we dare to say that the rights and freedoms of citizens are mainly regulated in the public sphere and, thus, mainly provided through the activities of law enforcement officials. We can also argue that Ukrainian law involves quite uncommon legal means to ensure the rights and freedoms of citizens in many spheres of their lives $/ \mathbf{3} /$.

Economic, political, and ideological transformations in Ukraine make the issue of protection of rights and freedoms particularly relevant in scientific and practical aspects. There is an urgent need to create an effective law enforcement system that meets modern requirements, considers the latest achievements in legal science, and aims to fulfill practical tasks concerning law enforcement. Therefore, an increased interest in the topic of law enforcement activity among lawyers and society is understandable /4/. As known, the protection of human rights is an acute problem in the Ukrainian reality since the creation of a guarantee system does not ensure the automatic exercise of human rights and freedoms. Thus, it is relevant to establish a mechanism for protecting human and civil rights as a system of means and factors that provide conditions for respect for rights and freedoms. However, the notion of law enforcement officials and the determination of their imposed duties cause legal uncertainty in Ukraine today. In this regard, the key point is to be aware of the place human rights and freedoms take in the activities of law enforcement officials and their importance for the protection of these rights.

Moreover, Ukraine dominates in the number of appeals to the European Court of Human Rights among the member states of the Council of Europe, which indicates the imperfection of the human rights protection system. Moreover, statistics show that the largest number of lawsuits accounts for the breach of human rights by law enforcement officials $/ 5 /$. This also proves the existing problem in Ukraine that bodies who have to protect human rights, in fact, break them. The above problems need to be solved as soon as possible. Thus, the article aims to explore the role of law enforcement activities in ensuring and protecting human rights in Ukraine, examine existing problems at the legislative and practical level, and find ways to improve the current situation.

In the course of the research, we applied a system of general scientific, philosophical, and special methods, which allow us to obtain reliable results and achieve the set aim. We used the legal-formal method to analyze the notion of law enforcement officials by the laws of Ukraine and examine the general principles of human rights protection by the norms of Ukrainian law and international law. In addition, the formal-legal method is used to analyze the case law of the European Court of Human Rights. Methods of scientific knowledge are used to study the features of law enforcement activities concerning the protection of human rights. The system method allowed us to 
generalize information on the features of law enforcement activity and its relationship with the protection of human rights. By the method of analysis and synthesis, we processed theoretical information, international legal acts, case law and, on their basis, identified problems existing in the research area and found ways for their solution.

\section{THE ESSENCE OF LAW ENFORCEMENT OFFICIALS IN UKRAINE}

Studying the place human rights take in the system of law enforcement officials, the consideration of the importance of such bodies in the state will make sense. Article 17 of the Constitution of Ukraine of 1996 states: “...Ensuring the security of the State and protecting the State borders of Ukraine shall be entrusted to respective military formations and law enforcement officials of the State, whose organization and operational procedure shall be determined by law" /6/. Based on this definition, we can argue that law enforcement officials, according to the Basic Law of Ukraine, are bodies responsible for ensuring the state security and protection of the state border. Thus, the given definition does not indicate that law enforcement officials are obliged to act for the benefit of the protection of human rights and freedoms. We believe their activities are much broader and aimed, first of all, at ensuring proper order within the state by protecting the rights and freedoms of citizens.

The domestic researcher V.V. Nahorna /7/ holds a similar opinion, noting that the activities of law enforcement officials should not guarantee only state security and state control but also protect human and civil rights and freedoms, public order, and national interests of Ukraine. However, Article 3 of the Constitution of Ukraine states that "human rights and freedoms, and guarantees thereof shall determine the essence and course of activities of the State. The State shall be responsible to the individual for its activities. Affirming and ensuring human rights and freedoms shall be the main duty of the State" /8/. That is, respect for human rights is the main duty of the state. This gives us the right to argue that the state should aim its activities at protecting its citizens and persons who legally stay in the country. Since the state ensures respect for the rights of every person, law enforcement officials as public authorities should aim their activities at protecting human rights. Moreover, regarding the very name of these bodies, which includes the adjective "law-enforcement," we can assert that the main indicator of their activity, in any case, must be the protection of laws. Therefore, they must act exclusively in the legal field, including the legal protection of human rights.

Article 2 of the Law of Ukraine On State Protection of Court and Law Enforcement Officials dated 1993 /9/, as amended, lists the bodies that are classified as law-enforcement, namely: prosecution agencies, the National Police, the security services, the Ukrainian Military Law-Enforcement Service, National Anti-Corruption Bureau of Ukraine, the State Border Guard Service, bodies of fiscal service, penitentiary bodies and offices, pre-trial detention centers, state financial control bodies, fishery protection bodies, state forest protection bodies, other bodies performing law enforcement functions. Thus, under the Law of Ukraine, this notion involves all bodies that enforce the law and protect it from being broken.

In domestic science, many researchers have also given their definitions of the notion of law enforcement officials. For example, Ukrainian scientists A.M. Kolodii and A.Yu. Oliinyk /10/ emphasize that law enforcement officials are structured groups of employees who perform state and nonstate functions of control, supervision, pre-trial investigation, protection and defense of all forms of property, protection of nature, protection of human and civil rights, freedoms, and legitimate interests, other law enforcement functions.

The very name of law enforcement activity indicates that it aims to protect human and civil rights and freedoms, public order, ensure public safety, and maintain law and order. The importance of law enforcement officials is to comply with the 
imposed responsibilities in the following areas: national security and protection of public order; protection and defense of the rights and legitimate interests of citizens, enterprises, organizations, institutions, subjects of all forms of ownership; protection of the sovereignty and territorial integrity of Ukraine /11/.

Besides, there is the following interpretation of law enforcement officials in the scientific literature: a state-owned institution that operates within the system of government agencies and performs state functions under the law in various areas of internal and external activity of Ukraine (power, organizational management, monitoring, and checkout, etc.) /12/. Law enforcement officials can also be defined as public authorities, aimed by functional criterion at the professional implementation of law enforcement activities to ensure the rule of law and order, protect from unlawful encroachments on rights, freedoms, and legitimate interests of individuals and legal entities, interests of society and the state $/ \mathbf{1 3} /$. The Analytical Note of the National Institute for Strategic Studies states that law enforcement officials are public authorities whose main duty is to carry out law enforcement activities /14/.

Thus, even if the notion of law enforcement officials causes uncertainty at the legislative level, the protection of human and civil rights, freedoms, and legitimate interests are emphasized in definitions by domestic researchers as the key function of such bodies as well as the state. Anthropocentrism is a basic principle for the functioning of the world order, which cannot be neglected in a modern developed democratic society. Therefore, a key, central activity of law enforcement officials is to protect human rights and freedoms.

The state must take an active part in ensuring human rights and creating material, organizational, social, political, and other conditions for the person to exercise his or her rights and freedoms to the full extent. Since the creation of a guarantee system does not ensure the automatic exercise of human rights and freedoms, the protection of human rights presents an acute problem in modern Ukraine. Therefore, law enforcement officials in Ukraine are instrumental in the protection of human rights and freedoms. In this regard, one should know what bodies the term "law enforcement officials" encompasses and where their activities are directed.

The principles of humanity, legality, respect for human and individual rights, social justice, and close interaction with the population should be integral to law enforcement activities. These principles are intended to ensure the protection of rights and the application of coercive measures to remove obstacles for a person to exercise his or her rights and responsibilities, resume violated rights, freedoms, or legitimate interests, hold a liable to justice $/ \mathbf{1 5} /$.

When exercising rights and freedoms, only restrictions established by law apply to each person. The restrictions established by law can apply to rights and freedoms only if they ensure the recognition and respect for the rights of others and comply with fair requirements of morality, public order, and the common welfare in a democratic society. Every person has the right to take part in the government of his or her country, directly or through elected representatives. The government power is built on people's will through periodic and genuine elections, held under the conditions of universal and equal right to vote. Each law enforcement official represents the interests of the whole society and is accountable to it. All law enforcement officials are part of society and must serve it.

\section{INTERNATIONAL HUMAN RIGHTS STANDARDS IN LAW ENFORCEMENT}

In general, the issue of human rights protection in law enforcement activities follows from universal international conventions on the protection of human rights. At the same time, there are some international acts, which provisions aimed at direct regulation of law enforcement activities. We should pay attention to the Code of Conduct for Law Enforcement Officials adopted by UN 
General Assembly at its 34th session in 1979 /16/. It is a framework document that regulates the limits of the lawful conduct of officials and outlines some organizational and legal framework for law enforcement activities.

This international document consists of eight articles with an explanatory commentary on each of them. In general, we can briefly describe the content of this document. It stipulates that law enforcement officials shall execute the duties imposed on them by law. The Code also states that law enforcement officials shall respect and defend human dignity and uphold and protect human rights. The commentary lists international human rights instruments related to law enforcement. Among them, there are the Universal Declaration of Human Rights, 1948; the International Covenant on Civil and Political Rights, 1966; the Declaration on the Protection of All Persons from Being Subjected to Torture and Other Cruel, Inhuman or Degrading Treatment or Punishment, 1975; the International Convention on the Elimination of All Forms of Racial Discrimination, 1965; the International Convention on the Suppression and Punishment of the Crime of Apartheid, 1948, etc. The document also specifies that law enforcement officials may use force only when strictly necessary and to the extent required for the performance of their duty.

In addition, the Code also stipulates when law enforcement officials obtain information of a confidential nature, they shall keep it confidential unless the performance of duty or the needs of justice strictly require otherwise. The provisions of the act also regulate the absolute prohibition of torture or any other cruel treatment. It also notes that law enforcement officials may not invoke superior orders or exceptional circumstances such as a state of war or a threat to national security as a justification of torture. As stated in the Code, law enforcement officials shall provide full protection of the health of persons in their custody. According to the Code, law enforcement officials shall not support any act of corruption, shall respect the law, and prevent and oppose any violation of it.

Thus, this international legal act proves that the issue of respect for human rights in the activities of law enforcement officials is relevant and does not lose its significance for the development of states.

In addition, we find the issue on the individual responsibility of law enforcement officials in many other international legal acts. Let us consider some of them:

- Convention against Torture and Other Cruel, Inhuman or Degrading Treatment or Punishment, 1975 (an order from a superior officer or a public authority may not be invoked as a justification of torture. This provision concerns any public official or person acting in an official capacity, and therefore, law enforcement officials);

- the above Code of Conduct for Law Enforcement Officials, 1979 (need to report violations. In fact, the requirement is that law enforcement officials who have reason to believe that there has been or will be a violation of the Code shall report the matter to their superior authorities and, where necessary, to other appropriate authorities or organs empowered with reviewing or legal control);

- $\quad$ Basic Principles on the Use of Force and Firearms by Law Enforcement Officials dated 1990 (governments and law enforcement officials shall ensure that officials are held responsible if they know or should have known about the unlawful use of force and firearms, and they did not take all measures in their power to prevent, suppress or report such use);

- Body of Principles for the Protection of All Persons under Any Form of Detention or Imprisonment dated 1988 (it includes one of the principles containing several provisions on the need to report such violations. Paragraph 2 of Principle 7 stipulates that officials who have 
reason to believe that a breach of the Code of Principles has occurred or may occur shall report the appropriate authorities empowered with reviewing or remedial powers) and others.

In entrenched democracies, the political aspects of law enforcement are generally ignored or underestimated. This trend is mainly due to the desire to maintain objectivity and impartiality, and however, it may cause underestimation of some complex political situations. Though, if we regard the activities of law enforcement officials in the broadest sense, it is extremely politicized. This activity can be objective and impartial, provided that law enforcement officials understand their obligation to serve not a particular government or regime but the people $/ \mathbf{1 7 /}$.

\section{PROBLEMS OF UNDERSTANDING THE PROTECTION OF HUMAN RIGHTS IN LAW ENFORCEMENT}

The protection of human rights is fundamental to the maintenance of a genuine and stable order within the state. When the rule of law is not maintained, serious and systematic human rights violations occur. As a result, disrespect for the law and public authorities grows, and open conflict

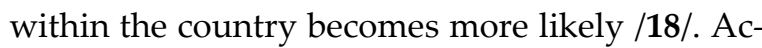
cording to official data, Ukraine was ranked third in the number of appeals to the European Court of Human Rights by its citizens at the end of 2020 (hereinafter - ECtHR) /19/. Thus, in the states, which do not uphold the rule of law and, in the person of its bodies, violate human rights, there will be constant conflicts with society. Therefore, even though the legal acts of Ukraine proclaim the principle of the rule of law, the real situation is alarming. Moreover, Ukraine has been ranked the leading position for many years. This is a warning sign and an indication that the state often neglects the rights of its citizens.

The statistics of the Council of Europe on appeals to the European Court of Human Rights shows that Ukrainians appeal to the Court due to the following violations: unreasonable length of court proceedings; torture and inhumane conditions of pre-trial detention facilities or in places of executing punishment; ineffectiveness of investigations conducted by law enforcement officials and complaints of cruel treatment by such authorities; failure to provide required medical care to persons in pre-trial detention facilities or places of executing punishment; lack of proper conditions for detention places; violation of the right to a fair trial /20/. Thus, among the above, the leading are violations of rights by law enforcement officials and judicial bodies, although they have to protect such rights. The Court delivered judgments in 109 cases in 2020, whereby it recognized violations by Ukraine in 66 cases, i.e., more than half of the cases did contain violations by the state $/ \mathbf{2 1} /$. According to the statistics, the ECtHR delivered 1,413 judgments in cases of Ukraine during 19592019. This makes Ukraine to be ranked fifth among 47 member states of the Convention in the number of judgments delivered on them /22/.

All the above points that law enforcement officials work imperfectly and have little awareness that the protection of citizens is the basis of their activity, where human rights should take the central place.

To better understand the scale of the problem, let us consider cases against Ukraine on human rights violations judged by the European Court of Human Rights. All judgment on cases were delivered in 2020. We take only four cases for analysis, although, in fact, there are many more.

The first case to be considered is Svirgunets v. Ukraine, No. 38262/10 of $2020 / 23 /$, in which the applicant complained under Article $6 \S 1$ of the Convention for the Protection of Human Rights and Fundamental Freedoms of 1950 that law enforcement officials had violated her right to a reasonable length of the criminal proceedings. The criminal proceedings against the applicant were initiated in 2002 and completed only in 2012. The applicant believed that her right to be tried within a reasonable term had been violated. 
The ECtHR emphasized in its judgment that the reasonableness of the length of the proceedings must be assessed under the circumstances of the case and about the following criteria: the complexity of the case and the conduct of the applicant and the relevant authorities. The present case against the applicant began on 14 May 2002 and ended on 29 January 2012. Thus, the duration was more than 9 years and 8 months. The Court held that the criminal case at issue, which involved one incident and two co-accused, was not complex. The ECtHR also found no evidence that the applicant herself had contributed to the delay in the proceedings.

An important component is the direct conduct of the authorities, as the case has been referred for retrial several times due to breaches of the rules of criminal procedure during the investigation and subsequent trials. Given this, the ECHR notes if such judgments occur in one stage of the proceedings, it may indicate serious shortcomings in the judiciary. Considering all the above, the Court holds that the length of the criminal proceedings against the applicant in the present case was excessive and did not meet the reasonable time requirement. There has accordingly been a breach of Article $6 \S 1$ of the Convention, dated 1950.

This case is an important example of judicial practice. It clearly shows the violation of human rights by all those bodies that belong to the law enforcement and should protect such rights, namely judicial and investigative bodies, the police. Even though the applicant in the criminal case was an accused person, the law enforcement officials were not entitled to violate her legal rights and interests in any way. Moreover, the ECtHR has rightly noted that the present case showed all the shortcomings of law enforcement officials of Ukraine that must be corrected and eliminated soon.

The circumstances of the case Povarov v. Ukraine,

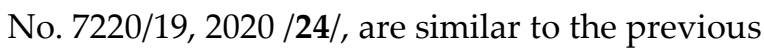
one. According to the circumstances, the applicant complained that law enforcement officials had detented him unreasonably long during the pre-trial investigation. There has accordingly been a breach of Article $3 \S 5$ of the Convention for the Protection of Human Rights and Fundamental Freedoms dated 1950, which states: “... shall be entitled to trial within a reasonable time or to release pending trial. Release may be conditioned by guarantees to appear for trial." In addition, the applicant also complained about the lack of compensation for unlawful detention and the excessive length of the criminal proceedings.

In its judgment, the ECtHR found that the criminal proceedings were excessively long and exceeded reasonable time, and on that basis, noted a violation of the Convention of 1950 . In addition, the Court found the lack of compensation to the applicant for unlawful detention, which is recognized as a violation under Article $5 \S 5$ of the Convention of 1950 .

Dykusarenko v. Ukraine, case No. 17854/19, $7218 / 19$ dated 2020, is interesting for the research topic. The applicant complained under Art. 3 and 13 of the Convention of the improper conditions of his detention and the lack of an effective legal remedy in domestic law. The applicant also complained under other provisions of the Convention of 1950 and the well-established case-law of the ECtHR of the excessive length of his pre-trial detention, the lack of compensation for unlawful arrest or detention, and the excessive length of criminal proceedings. We should note that the applicant was being held in Dnipro detention facility No. 4 at the moment of applying to the ECtHR.

Having considered the applicant's complaint on inadequate conditions of detention, the ECtHR noted that the serious lack of space in a prison cell weighs heavily as a factor and can establish, both alone or taken together with other shortcomings, whether the detention conditions described are "degrading." The Court concluded that the applicant's conditions of detention were inadequate, stated that the applicant had no effective remedy in respect of his complaints, and held a violation of the Convention of 1950. 
In addition, the ECtHR also holds that there has been a violation under other Articles, namely, excessive length of pre-trial detention and no effective right to compensation in the domestic legal system $/ 25 /$.

Finally, let us turn our attention to case No. $52234 / 18$ Kasyanenko v. Ukraine of 2020. In this complaint, the applicant noted that the length of the criminal proceedings had been incompatible with the "reasonable time" requirement and that he had no effective legal remedy in this regard. Thus, Article $6 \S 1$ of the Convention states: "In the determination of ... any criminal charge against him, everyone is entitled to a ... hearing within a reasonable time by a ... tribunal." At the same time, the provisions of Art. 13 of the Convention stipulate: "Everyone whose rights and freedoms as set forth in this Convention have been violated shall have an effective remedy before a national authority notwithstanding that the violation has been committed by persons acting in an official capacity."

Having considered the circumstances of the case, the Court reiterated that the reasonableness of the length of the proceedings must be assessed under the case circumstances and with reference to the following criteria: the complexity of the case, the conduct of the applicant and the relevant authorities, and what was important for the applicant in the dispute.

Relying on its case-law on the subject, the ECtHR considers that the length of the proceedings in the present case was excessive and did not meet the "reasonable time" requirement. The Court further notes that the applicants did not have an effective remedy in respect of these complaints $/ 26 /$. Thus, we can state that the problem of human rights violations by law enforcement officials exists in Ukraine, which is confirmed by the caselaw of the European Court of Human Rights. These cases are not single examples, as there are many other cases of rights violations by law enforcement officials, who, in fact, shall protect them.
In the Reference edition of the International Committee of the Red Cross "International Rules and Standards for Policing," dated 2015, it is noted that the state has to maintain law and order, peace and security within its whole territory. The structures set up by the state for that purpose shall ensure that law enforcement is carried out in compliance with the state's obligations under international human rights law. This means that both domestic legislation and the practice used by law enforcement officials must comply with applicable norms of human rights. The state is obliged to respect human rights, protect human rights, ensure and fulfill human rights and ensure the absence of discrimination /27/.

Being representatives of the state, law enforcement officials have to fulfill the above obligations when performing their duties, namely, maintain public order, prevent and detect crimes, and provide assistance in any emergency. They are given special powers that allow them to achieve their tasks. However, when exercising these powers, they are obliged to respect human rights, i.e., observe the four basic principles that the state must be guided by in any action with a possible impact on human rights:

- the principle of legality: provisions of the law must be a basis for all actions;

- the principle of necessity: they should not restrict human rights more than is required;

- the principle of proportionality: their impact on human rights must comply with their objectives;

- the principle of accountability: those who take action should be fully accountable at all appropriate levels (to the judiciary, to the public, to the government, and within the internal system of subordination) $/ \mathbf{2 8} /$.

One should understand the above principles as starting points, indisputable requirements for such a public activity as the protection of rights. When improving the system of law enforcement 
officials and organizations, these principles need to be considered. If only law enforcement officials fully observe the above principles, it can guarantee the observance of democratic principles and the legal character of the law enforcement system as a whole and, directly, the state.

\section{IMPERFECTIONS IN LAW ENFORCEMENT}

The Ukrainian researcher Yu.V. Delia /29/ reveals the problems in defining the notion of law enforcement. During the years of independence of Ukraine, as the researcher emphasizes, an appropriate legal framework has been created for law enforcement officials to effectively protect human and civil rights, freedoms, and legitimate interests. However, the most important step, regulation of the notion, has not been taken. This has caused the legislation of Ukraine to suffer a large number of gaps, inaccuracies, contradictions that give rise to problems of theoretical, legal, and practical nature. In his work, the researcher proposes how to address the above problems and suggests his approaches to defining legal notions.

Domestic researcher V.V. Nahorna /30/ also concludes that the legal regulation of law enforcement officials is imperfect and prompts legal uncertainty about the discussed notion. As she noted, it is reasonable to distinguish the main features of law enforcement officials and provide their definitions at the scientific and theoretical levels. As for the legislative level, the researcher believes the notions of law enforcement officials and law enforcement functions should be defined, and a separate law regulating the activities of such bodies must be created, such as the Law of Ukraine On Status of Law Enforcement Officials.

N.I. Konstantinova /31/, a domestic researcher and journalist, studied the ECtHR case law in cases of Ukraine and brought together important issues, which primarily concern human rights violations by law enforcement officials. She also provides important statistics to demonstrate the place Ukraine takes in the number of appeals against it among the general case law of the Court.

Another Ukrainian researcher, V.H. Hrytsenko $/ 32 /$, drew important conclusions on the activities of law enforcement officials in the protection of human rights through the functions of such bodies, noting that such activities are many-sided. The functioning and implementation of direct links between law enforcement officials are due to the need to obtain and use information, but this is not always possible through protocol and formal interaction.

Separate aspects of human rights in law enforcement were studied by V.V. Barbin /33/, V.P. Bieliaiev /34/, I.V. Zozulia /35/, O.P. Kuchynska /36/, O.L. Sokolenko /37/, and others /38/.

Although many researchers and scientists have dedicated their works to this issue, it remains insufficiently studied and debatable in legal science /39/. In particular, insufficient attention is paid to the compliance of domestic legal norms with international legal requirements and standards. In addition, the article highlights the case-law of the European Court of Human Rights, which shows the urgent problems related to law enforcement officials in Ukraine.

\section{CONCLUSION}

Thus, a law enforcement body is a jurisdictional body empowered by Ukrainian society to perform as prescribed by law functions or tasks to protect law and order, investigate or prevent rights violations, restore the violated right, protect national (state) security, maintain law and order. In any case, the state is created by citizens to protect them. Observance of human rights and freedoms, protection of their interests, creation of decent living conditions, protection from external threats are the main tasks of the state. Citizens run the state, not vice versa. This is how any democratic society functions. Therefore, if the state follows this principle, law enforcement officials or any other public authorities should direct their activities to protect human and civil rights and 
ensure public peace and general security within the state. A developed society can function so and in no other way.

The protection of human rights and freedoms is central to the work of law enforcement officials. The scientific researches, the UN recommendations, the features of the state and its authorities confirm the stated above. A distinctive feature of law enforcement officials is that they represent the entire state in relations with the person and often must restrict human rights and freedoms within the statutory limits when protecting the state interests. However, these restrictions are possible only if they ensure the recognition and respect for the rights of others and comply with fair requirements of morality, public order, and the common welfare. The legal regulation and duties imposed on their employees greatly influence the work performance of law enforcement officials. These duties must be based on the principles of humanity and respect for the rights and freedoms of citizens. The activity of law enforcement officials can be more effective if it is regulated in detail by regulatory legal acts. This is especially necessary regarding modern conditions of reforming the law enforcement system.

Law enforcement officials are obliged to address many issues related to the protection of human rights and interests. It follows that the exercise of constitutional rights and freedoms is not possible without ensuring the proper functioning of public authorities, namely, law enforcement officials. It is their activity that shows human freedom in the state in practice. Therefore, being their main function, it includes various aspects, namely: create guaranteed conditions for the exercise of rights in public places and protect criminally violated ones with the application of the most severe coercive measures under the law.

First of all, it is necessary to arrange regulatory and legal acts that regulate the concept of law enforcement officials and eliminate gaps in them, including the Constitution of Ukraine. Moreover, it is needed to clearly define the principles of law enforcement applied to ensure human rights and freedoms, their constitutional guarantees, and the procedure for their ensuring. Law enforcement officials must issue internal acts for officials in compliance with the requirements and standards of international law on human and civil rights and freedoms.

We believe, to improve the situation with respect for human rights and freedoms, it is also possible to organize public opinion polls, which would help to analyze and assess the effectiveness of law enforcement officials in Ukraine, and develop online platforms for society to participate in law enforcement and rapidly communicate with regulatory authorities. The implementation of the platform for monitoring law enforcement officials is quite possible given the initiative of V. Zelensky, the current President of Ukraine, which aims to facilitate the access and contact of citizens with government officials via the Internet. Also, such a system can help to monitor the law enforcement activities and prepare periodic analytical reports on respect for human rights by law enforcement officials in Ukraine. We hope that this initiative will help to improve human rights protection and reduce the number of applications to the ECtHR on human rights violations by public authorities, including law enforcement.

In addition, it is necessary to change the methods of training and development of law enforcement officers, so they clearly feel the need to take all measures to protect human and civil rights and interests and act as a guarantor of such rights since the very beginning of performing their direct professional duties. The function system of law enforcement officials should be cardinally changed so that citizens can rely on, trust, and respect such officials.

The theoretical significance of the study lies in the in-depth and comprehensive analysis of the legislation of Ukraine aimed at defining the notion of law enforcement officials and regulating this issue at the domestic legal level and in international law. The practical significance of the study is that 
we have suggested amendments to the legislation of Ukraine. In addition, we have argued that the creation of the online platform and public initiatives is essential to change the practical regulation of law enforcement control in terms of their respect for human rights and freedoms.

Notes

/1/ Banchuk, O.A. (2013), Police status: international standards and foreign legislation. Kyiv: CPPR.

/2/ Ivantsova, T.G. (2016), The role of law enforcement agencies in the observance and protection of human rights in Russia. Tavrichesky Scientific Observer, 12(17), 46-48.

/3/ Admiralova, I.A. (2016), On the issue of the administrative activities of the police and ensuring the rights and freedoms of citizens. Police Activity, 5, 449-455.

/4/ Nalyvaiko, L.V. (2019), Protection and observance of human rights in law enforcement. Retrieved from https://dduvs.in.ua/wp-content/uploads/files/Structure/library/student/lectures/2020/kzpd/121.1.pdf

/5/ Konstantinova, N. (2020), 95\% of complaints to the ECtHR from Ukrainians concern non-enforcement of court decisions. Retrieved from https://www.radiosvoboda.org/a/devianosto-piat-vidsotkivskarg-do-yevrosudu-vid-ukrainsiv-stosuyutsianevykonannia-sudovyh-rishen/30962110.html

/6/ Constitution of Ukraine. (1996), Document No. 254k / 96-BPP. Retrieved from https://zakon.rada.gov.ua/laws/show/254\%D0\%BA/96\%D0\%B2\%D1\%80\#Text

/7/ Nahorna, V.V. (2018), On the problem of defining the concept of "law enforcement agencies" in legal science and legislation of Ukraine. Legal Scientific Electronic Journal, 6, 44-48.

/8/ op. cit. in /6/

19/ Verkhovna Rada of Ukraine. (1993), Law of Ukraine “On State Protection of Court and Law Enforcement Officials" No. 3781-XII. Retrieved from https://zakon.rada.gov.ua/laws/show/3781-12\#Text

/10/ Kolodii, A.M. \& Oliinyk, A.Yu. (2009), Jurisprudence: a textbook. Kyiv: Legal unity.

/11/ Voluiko, O. \& Druchek, O. (2020), The concept of law enforcement and law enforcement agencies in the light of the concept of national security of Ukraine. Entrepreneurship, Economy and Law, 10, 95-100.
/12/ Maliarenko, V.T. (2007), Court, law enforcement and human rights bodies of Ukraine: textbook. Kyiv: Yourinkom Inter.

/13/ Farion-Melnyk, A. \& Yaremko, O. (2020), Law enforcement: issues of terminology and system. Current Issues of Jurisprudence, 2. Retrieved from http://appj.wunu.edu.ua/index.php/appj/article/view/998

/14/ Hyrych, V.M. (2013), “On the problem of defining basic concepts in the context of law enforcement reform." Analytical note of the National Institute for Strategic Studies. Retrieved from http://old2.niss.gov.ua/articles/1153/\#_ftn2

/15/ Kobzar, O.F. (2014), The role and activities of law enforcement agencies in the mechanism of ensuring the rights and freedoms of citizens. Visegrad Journal on Human Rights, 2, 135-139.

/16/ United Nations General Assembly. (1979), Code of Conduct for Law Enforcement Officials. Retrieved from http://docs.cntd.ru/document/901739106

/17/ Lasso, H. (2015), Fundamental concepts. Part two. Retrieved from https://www.ohchr.org/Documents/Publications/training5Introru.pdf

/18/ Human Rights and Law Enforcement. (2002), A Trainer's Guide on Human Rights for the Police. Office of the United Nations High Commissioner for Human Rights. Retrieved from https://www.ohchr.org/Documents/Publications/training5Add2ru.pdf

/19/ European Court of Human Rights Statistics. (2020), Retrieved from https://www.echr.coe.int/Documents/Stats_analysis_2020_ENG.pdf

/20/ op. cit. in /5/

/21/ op. cit. in /5/

/22/ Shenk, O. \& Tolochko, V. (2020), 5 decisions of the ECtHR in 2020 that are worth paying attention to. Legal Newspaper, 22(728). Retrieved from https:/yur-gazeta.com/publications/practice/sudova-praktika/5-rishen-espl-2020-roku-na-yakivarto-zvernuti-uvagu.html

/23/ European Court of Human Rights. (2020), Case of Svirgunets v. Ukraine. Application No. 38262/10. Retrieved from https:/hudoc.echr.coe.int/eng\#\{\%22itemid\%22:[\%22001202413\%22]\}

/24/ European Court of Human Rights. (2020), Case of Povarov v. Ukraine. Application No. 7220/19. Retrieved from https:/www.stradalex.com/en/sl_src_publ_jur_int/document/echr_7220-19 
/25/ European Court of Human Rights. (2020), Case of Dykusarenko v. Ukraine. Application No. $7218 / 19$ and 17854/19. Retrieved from https://www.stradalex.com/en/sl_src_publ_jur_int/document/echr_17854-19_7218-19_001-202222

/26/ European Court of Human Rights. (2020), Case of Kasyanenko v. Ukraine. Application No. 52234/18. Retrieved from https://hudoc.echr.coe.int/eng\#\{\%22appno $\% 22:[\% 2252234 / 18 \% 22], \% 22$ itemid $\% 22:[\% 220$ 01-203566\%22]\}

/27/ International Rules and Standards for Policing. (2015), Reference book of the International Committee of the Red Cross. Retrieved from https://shop.icrc.org/icrc/pdf/view/id/2540

/28/. op. cit. in /17/

/29/ Delia, Yu.V. (2020), Law enforcement agencies in the field of protection of rights, freedoms and legitimate interests of man and citizen. Legal Magazine of Donbass, 1(70), 208-218.

/30/ op. cit. in /7/

/31/ op. cit. in /5/

/32/ Hrytsenko, V.H. (2017), The concept and significance of the functions of law enforcement agencies. Scientific Bulletin of Kherson State University, 2, 20-23.

/33/ Barbin, V.V., Borisov, A.V., Goncharov, I.V., Kirichyok, E.V., Korabelnikova, Yu.L., Kosykh, A.A., Matantsev, D.A., Pozharsky, D.V., Ryzhova, Yu.V., \& Stepkin, E.Yu. (2020), Ensuring human and civil rights and freedoms in the activities of public authorities. Moscow: Academy of Management of the Ministry of Internal Affairs of Russia.

/34/ Bieliaiev, V.P. \& Larina, O.G. (2017), Formation of the Institute of State Control. History of State and Law, 17, 18-24.

/35/ Zozulia, I.V. (2012), Regarding the participation of the law enforcement system in the implementation of the national security strategy of Ukraine. Forum of Law, 4, 389-394.

/36/ Kuchynska, O.P., Fulei, T.I., \& Barannik, R.V. (2013), Principles of criminal proceedings in the light of the case law of the European Court of Human Rights: a monograph. Nizhyn: AspectPolograf.

/37/ Sokolenko, O.L. (2015), Implementation of protection of citizens' rights in the activities of law enforcement agencies of Ukraine. Current Issues of Domestic Jurisprudence, 5, 54-61.

/38/ Kozlovskyi, S., Butyrskyi, A., Poliakov, B., Bobkova, A., Lavrov, R., \& Ivanyuta, N. (2019), Management and comprehensive assessment of the probability of bankruptcy of Ukrainian enterprises based on the methods of fuzzy sets theory. Problems and Perspectives in Management, 17(3), 370-381. DOI: 10.21511/ppm.17(3).2019.30

139/ Reznik, O., Getmanets, O., Kovalchuk, A., Nastyuk, V., \& Andriichenko, N. (2020), Financial security of the state. Journal of Security and Sustainability Issues, 9(3), 843-852. 